\title{
Subcutaneous and muscular lagochilascariasis in a cat from Rio Grande do Sul, Brazil
}

\author{
Bruna Marquardt Lucio ${ }^{1}$ (D) Mariana Martins Flores $^{1 *}$ iD
}

'Programa de Pós-graduação em Medicina Veterinária (PPGMV), Centro de Ciências Rurais, Universidade Federal de Santa Maria (UFSM), 97105-900, Santa Maria, RS, Brasil. E-mail: marianamflores@yahoo.com.br. "Corresponding author.

\begin{abstract}
A domestic cat was submitted to necropsy with a small abscess within the subcutaneous tissue and skeletal muscles dorsal to the left ear. It contained multiple 0.8 to $1.2 \mathrm{~cm}$-long adult nematodes and was drained by two cutaneous fistulae. On histopathology, multiple cavitary areas within the skeletal muscles and subcutaneous tissue contained adult nematodes and were surrounded by thick fibrotic and chronic-active inflammatory reaction. The parasites were externally lined by a smooth cuticle and had two prominent lateral alae. They contained an intestinal tract and a pseudocoelom. A prominent polymyarian-coelomyarian musculature and two large lateral chords were identified, and some sections contained a uterus with multiple non-operculated eggs. Lagochilascariasis should be considered a differential diagnosis for cervical skin abscesses in domestic cats from Southern Brazil. This article brings important contributions to the clinical and anatomopathologic diagnosis of this rare zoonotic disease.

Key words: zoonosis, lagochilascariasis, nematode, parasite.
\end{abstract}

Lagoquilascaríase subcutânea e muscular em um gato do Rio Grande do Sul, Brasil

RESUMO: Um gato doméstico foi submetido à necropsia com um pequeno abscesso no tecido subcutâneo e musculatura esquelética dorsal ao ouvido esquerdo. Continha vários nematódeos adultos de 0,8 a 1,2 cm de comprimento e foi drenado por duas fistulas cutâneas. Na histopatologia, múltiplas áreas cavitárias coalescentes dentro dos músculos esqueléticos e tecido subcutâneo continham nematódeos adultos e eram circundadas por espessa reação inflamatória fibrótica e crônica ativa. Os parasitas eram revestidos externamente por uma cutícula lisa e tinham duas asas laterais proeminentes. Eles continham um trato intestinal e um pseudoceloma. Uma musculatura polimiariana proeminente e duas grandes cordas laterais foram identificadas, e algumas seções continham um útero com múltiplos óvulos não operculados. A lagoquilascaríase deve ser considerada um diagnóstico diferencial para abscessos cutâneos cervicais em gatos domésticos do Sul do Brasil. Esse artigo traz importantes contribuições para o diagnóstico clínico e anatomopatológico dessa rara doença zoonótica.

Palavras-chave: zoonose, lagoquilascaríase, nematódeo, parasite.

Lagochilascariasis is a disease caused by the nematode Lagochilascaris spp.. The definitive hosts are wild felids; however, humans, dogs and cats can act as accidental hosts (FORTES, 1997). It is an emerging zoonosis in humans, especially in Central and South Americas (BARRERA-PÉREZ et al., 2012). In Brazil, human lagochilascariasis is common in northern states; although, it is considered rare to nonexistent in the south (PAÇÔ et al., 1999). In the other hand, feline lagochilascariasis is uncommon in this and other countries, with an even smaller number of cases in Southern Brazil (FACCIO et al., 2013, FELHBERG et al., 2014). Affected cats develop subcutaneous abscesses mainly located in the cervical region (FORTES, 1997; BARRERA-PÉREZ et al., 2012; MAULDIN
\& PETERS-KENNEDY, 2015). Reports of human and feline lagochilascariasis in Rio Grande do Sul State are rare, and the authors of this article were unable to find a detailed histopathologic description of the parasite in the literature. Reporting and exploring new cases of this zoonosis in southern Brazil is of major importance, not only because it is a health concern in cats, but also due to its zoonotic potential. Additionally, the histologic aspects of this parasite are not completely described in the international literature. This is important, since it may help confirming the infection in biopsy samples. This paper described a case of feline lagochilascariasis in southern Brazil, with emphasis on the histopathologic description of the adult nematodes. 
An adult female cat with no defined breed was admitted for necropsy at the Laboratório de Patologia Veterinária of the Universidade Federal de Santa Maria with a five-day history of sialorrhea, ataxia and tachypnea followed by spontaneous death. The animal was from Cerro Largo, RS (latitude: $28^{\circ} 9^{\prime}$ 2" South, longitude: 54 44' 19" west). At necropsy, the skin surrounding the left ear had small external perforations (fistula) (Figure 1A), and a small abscess containing approximately 20 adult nematodes was observed within the subcutaneous tissue and skeletal muscles subjacent to this area (Figure 1B). The parasites were up to $1.2 \mathrm{~cm}$ long, white, filiform and cylindric. On microscopy, the head of the parasite had a prominent cleft that formed a groove. Some females were filled with eggs; these latter measured approximately $60 \times 55 \mu \mathrm{m}$, were more oval than round, had one uninucleate central zygote each and were covered by a thick, irregular shell with 29 to 35 pits. The parasite was identified as Lagochilascaris sp.. Tissues were fixed in $10 \%$ formalin and routinely processed for histologic analysis. On histopathology, multiple coalescing cavitary areas within skeletal muscles and subcutaneous tissue contained adult nematodes admixed with necrotic debris and degenerate neutrophils. These cavitations were surrounded by a thick tissue reaction constituted of an internal layer of necrosis and an outer layer of granulation tissue with admixed macrophages and plasma cells (Figure 1C). Transverse sections of the parasite were 800 to $1000 \mu \mathrm{m}$-wide and were lined by a thick, eosinophilic, smooth cuticle containing two external lateral alae (Figure 1D). The parasites had a pseudocoelom, an intestinal tract and a

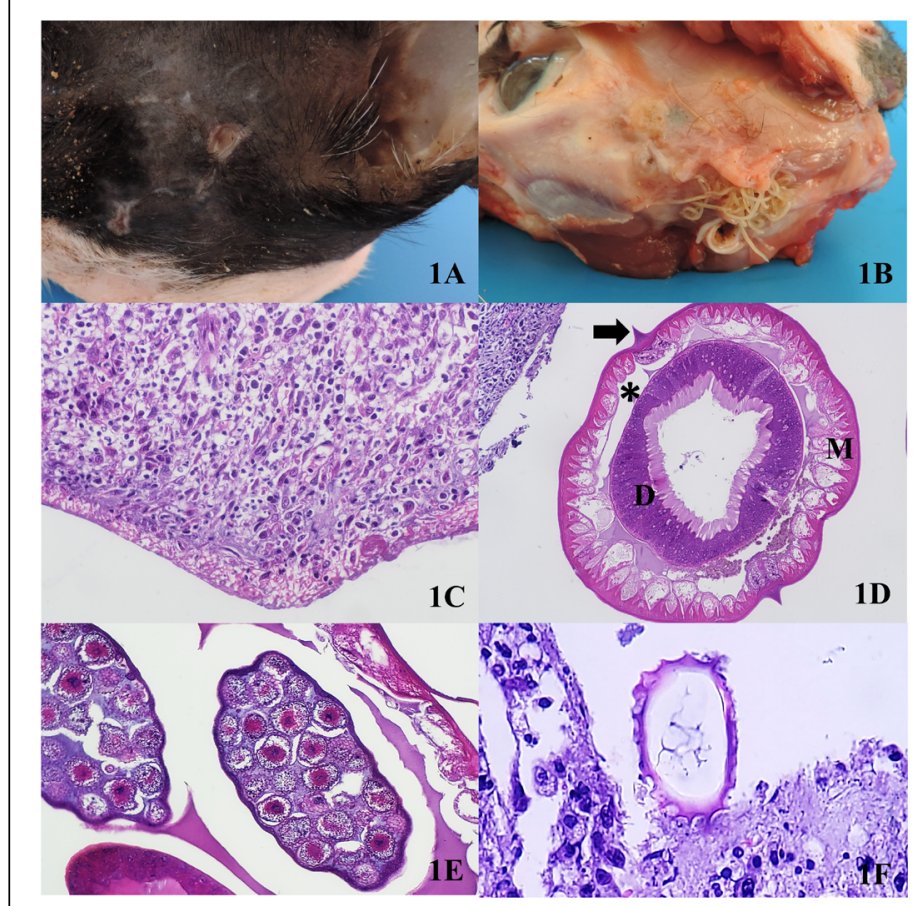

Figure 1 - A. The skin surrounding the left ear has small perforations (fistula). B. Subcutaneous tissue containing multiple nematodes. C. Abscess wall constituted of an internal layer of necrosis and an outer layer of granulation tissue with admixed macrophages and plasma cells (Hematoxylin and eosin [HE], Obj. 20X). D. Transverse section of an adult nematode. Note the external lateral alae (arrow), pseudocoelom (asterisk), digestive tract (D) and prominent musculature (M) (HE, Obj. 40X). E. Parasite uterus containing multiple eggs (HE, Obj. 40X). F A single parasite egg within the subcutaneous abscess (HE, Obj. 100X). 
prominent polymyarian-coelomyarian musculature. The hypodermis expanded laterally to form two lateral chords. Occasionally, esophagus and intestinal tract lined by tall columnar cells were present. Some sections had a uterus with multiple thick-shelled, nonoperculated oval eggs (Figure 1E). Some eggs were free within the abscess (Figure 1F). Lagochilascariasis was confined to the skin and subcutaneous tissue; being therefore, considered an incidental necropsy finding. The cause of death was attributed to a concurrent non-related protozoal encephalitis. Perivascular brain inflammation associated with occasional bradyzoites led to a diagnosis of toxoplasmosis. Paraffin-embedded brain sections were submitted to Polymerase Chain Reaction for Toxoplasma gondii, however, the technique was inconclusive.

Lagochilascaris spp. is a rare Central and South American nematode. The definitive hosts are wild felids. However, domestic cats and dogs, and humans may also get infected and act as definitive hosts (FORTES, 1997). Brazilian cats have been reportedly infected with $L$. minor (FACCIO et al., 2013; FELHBERG et al., 2014) and L. major (AMATO et al., 1990). The nematode from this case report was not further identified. Many features of this parasite's natural life cycle remain obscure. Possibly, the larval stage takes place in an intermediate host, and the ingestion of these infected tissues by the definitive host completes the cycle (FORTES, 1997). Feline lagochilascariasis has been occasionally reported in Argentina (ROMERO \& LED, 1985), Uruguay (CASTRO et al., 2009) and Brazil (FACCIO et al., 2013, FELHBERG et al., 2014).

In $75 \%$ of the cases, the infection involves the formation of tumors in the subcutaneous tissue restricted to the cervical region and to the oropharynx (AMATO et al., 1990, FACCIO et al., 2013), which is compatible with the lesion observed in this cat. It is possible to identify the eggs within subcutaneous abscesses, or even in the feces, in cases involving oropharynx and esophagus (FORTES, 1997). The clinical identification of larvae and adult nematodes from the fistulated subcutaneous abscesses can also be performed in advanced infections (FORTES, 1997; FACCIO et al., 2013). Rarely, lagochilascariasis may manifest with locomotory difficulties, midriasis and other neurologic clinical signs due to erratic larval migration (BOWMANN et al., 2002). However, lagochilascariasis was confined to the skin in this case, and the neurological signs described by the owner were attributed to the protozoal encephalitis.

One of the main features of Lagochilascaris spp. is a prominent head cleft that forms a groove, giving the impression that the organism has "lips" (from the Greek: Lagos means 'hare' and cheilos means 'lips') (FORTES, 1997). On histology, the presence of a pseudocoelom and of an intestinal tract allows the confirmation of a nematode. Other typical histologic findings of this specific parasite include the presence of prominent lateral alae (GARDINER \& POYNTON, 1999). The aspect and location of the gross lesions and the presence and size of the adult specimens should be always analyzed when considering possible differential diagnoses. Dracunculus sp. is probably the main differential diagnosis for this case (MAULDIN \& PETERS-KENNEDY, 2015). Apart from being restricted to North American, it often affects the limbs, it induces solid ulcerated skin nodules and the adult specimens are longer, with females reaching 14 to $70 \mathrm{~cm}$ (BOWMANN et al., 2002; MAULDIN \& PETERS-KENNEDY, 2015). Anatrichosoma causes paw swelling and ulceration other than cervical abscesses (BOWMANN et al., 2002). Dirofilaria repens and Dipetalonema (Acanthocheilonema, Cercopithifilaria) grassii are classically associated with microfilaria, and not by the adult specimens (MAULDIN \& PETERS-KENNEDY, 2015).

There is no known association of feline lagochilascariasis with immunosuppressiveconditions (including FIV and FeLV infection). Unfortunately, it was not possible to determine the infection status of this cat for these retroviruses; nonetheless, protozoal encephalitis in adult cats are often associated with immunosuppressive states. Thus, the possibility of this cat being immunosuppressed is not ruled out, which would make it susceptible to both the protozoal encephalitis and the Lagochilascaris infection. This is the first report bringing a detailed histologic description of Lagochilascaris sp. infection in a cat. This manuscript brings important contributions to the clinical and anatomopathologic diagnosis of this rare zoonotic disease.

\section{ACKNOWLEDGEMENTS}

This work was supported by the Coordenação de Aperfeiçoamento de Pessoal de Nível Superior (CAPES): B.M. Lucio has a CAPES scholarship.

\section{DECLARATION OF CONFLICT OF INTEREST}

The authors declare no conflict of interest. The founding sponsors had no role in the design of the study; in the collection, analyses, or interpretation of data; in the writing of the manuscript, and in the decision to publish the results. 


\section{AUTHORS' CONTRIBUTIONS}

The authors contributed equally to the manuscript.

\section{REFERENCES}

AMATO, J. F. et al. Two cases of fistulated abscesses caused by Lagochilascaris major in the domestic cat. Memórias do Instituto Oswaldo Cruz, v.85, n.4, p.471 - 473, 1990. Avaible from: $\quad<$ https://doi.org/10.1590/s0074-02761990000400013>. Accessed: Nov. 20, 2018.

BARRERA-PÉREZ, M. et al. Lagochilascaris minor leiper, 1909 (nematoda: ascarididae) in Mexico: three clinical cases from the Peninsula of Yucatan. Revista do Instituto de Medicina Tropical de São Paulo, v.54, n.6, p.315 - 317, 2012. Avaible from: <http:// dx.doi.org/10.1590/S0036-46652012000600005>. Accessed: Oct. 24, 2018. doi: 10.1590/S0036-46652012000600005.

BOWMANN, D. D. et al. Feline clinical parasitology. Ames: Iowa State University Press, 2002, 469p.

CASTRO, O. et al. Two new records of helminth parasites of domestic cat from Uruguay: Alaria alata (Goeze, 1782) (Digenea, Diplostomidae) and Lagochilascaris major Leiper, 1910 (Nematoda, Ascarididae).Veterinary Patasitology, v.160, p.344-347, 2009. Available from: <https://doi.org/10.1016/j.vetpar.2008.11.019>. Accessed: Oct. 22, 2020. doi: 10.1016/j.vetpar.2008.11.019.

FACCIO, L. et al. Case report: feline infection by Lagochilascaris sp. in the State of Rio Grande do Sul, Brazil. Veterinary Parasitology, v.196, p.541 - 543, 2013. Available from: <https:// doi.org/10.1016/j.vetpar.2013.03.006>. Accessed: Feb. 02, 2019. doi: 10.1016/j.vetpar.2013.03.006.

FELHBERG, M. F. et al. Lagochilascariasis in cats (Felis catus domesticus) in southern Brazil. Journal of Feline Medicine and Surgery, v.16, n.12, p.1007 - 1009, 2014. Available from: $<$ https:// doi.org/10.1177/1098612X14525386>. Acessed: Nov. 27, 2018. doi: $10.1177 / 1098612$ X14525386.

FORTES, E. Parasitologia Veterinária, 1st edition (Icone), p. 376, 1997.

MAULDIN E.A. \& PETERS-KENNEDY J. Chapter 6. Integumentary System. In.: Maxie, M.G. Jubb, Kennedy, and Palmer's. Pathology of Domestic Animals. 6th edition (Elsevier), Vol.1, p.690, 2015.

GARDINER, C.H. \& POYNTON, S.L. An atlas of Metazoan parasites in animal tissues. 1 edition, American Registry of Pathology, Washington, DC, p.47, 1999.

PAÇÔ, J. M. et al. Wild rodents as experimental intermediate hosts of lagochilascaris minor leiper, 1909. Memórias do Instituto Oswaldo Cruz, v.94, n.4, p.441 - 449, 1999.Available from: <http:// dx.doi.org/10.1590/S0074-02761999000400003>. Accessed: Oct. 24, 2018. doi: 10.1590/S0074-02761999000400003.

ROMERO, J. R.; LED, J. E. A new case of Lagochilascaris major (Leiper 1910) in the Argentine Republic parasitizing the cat (Felis catus domesticus) [article in Spanish]. Zentralblatt fur Veterinarmedizin. Reihe B., v.32, n.8, p.575 - 582, 1985. Avaible from: <https://pubmed.ncbi.nlm.nih.gov/4072484/>. Accessed: Dec. 02,2018 